\title{
THE ROLE OF INVENTORY INVESTMENT PRACTICES ON INNOVATION PERFORMANCE OF AGRICULTURAL BASED INSTITUTIONS
}

\author{
Kehinde, Busola E. ${ }^{1 \star}$, Ogunnaike, Olaleke $\mathrm{O}^{2}$, Adegbuyi Omotayo $\mathrm{O}^{3}$, Kehinde, \\ Oladele J., ${ }^{4}$ llogho, Simon O. ${ }^{5}$, Adedugba, Adebayo T. ${ }^{6}$ \\ ${ }^{1}$ Covenant University, Ota, Ogun State, NGERIA, busola.kehinde@covenantuniversity.edu.ng \\ ${ }^{2}$ Covenant University, Ota, Ogun State, NGERIA, olaleke.ogunnaike@covenantuniversity.edu.ng \\ ${ }^{3}$ Covenant University, Ota, Ogun State, NGERIA, omotayo.adegbuyi@covenantuniversity.edu.ng \\ ${ }^{4}$ Covenant University, Ota, Ogun State, NGERIA, oladele.kehinde@stu.cu.edu.ng \\ ${ }^{5}$ Covenant University, Ota, Ogun State, NGERIA, simon.logho@covenantuniversity.edu.ng \\ ${ }^{6}$ Covenant University, Ota, Ogun State, NGERIA, adebayo.adedugbapgs@stu.cu.edu.ng \\ ${ }^{*}$ Corresponding Author
}

\begin{abstract}
Rapid investment in inventory has drastically changed the working and business environment of the agriculture industry, especially agricultural based institutions. The purpose of this study is to evaluate the role of inventory investment practices to explain on innovation performance of a selected agricultural based institution in Nigeria. This study evaluates the components of inventory costs as determinants of inventory investment in the selected agricultural based institution in Nigeria. The study contributes to knowledge by employing the use of survey research and simple random sampling technique to collect data from 98 agricultural students. The results of the regression analysis shows that the components of this model have an effect on inventory investment practices and innovation performance. This study found that inventory investment practices account for $38 \%$ of innovation performance. The study recommends that proper inventory investment practices be employed by these institutions to improve innovation performance.
\end{abstract}

Keywords: Investment, inventory, innovation, performance, institutions, agriculture

\section{INTRODUCTION}

The dilemma of an institution in today's competitive environment is cantered on providing customers with products and services at a low cost. Over the last decade, there has been an amplified pressure on institutions to widen the focus of innovation performance. However, with the process of liberation and globalization, there has been a radical change in the educational sector. These changes have resulted in agricultural based institutions being exposed to extreme competition while still trying to create a conducive learning environment for its students. 
In an environment exhibited by massive competition, technological improvement, increasing customer awareness, institutions that look forward to success must always hype its service availability as customers can shift their patronage to competing institutions. In recent years, many agricultural based institutions have raised the bar again by coordinating and collaborating with other institutions in their supply chain so as to respond to unknown and changing demand (Ogbo, Onekanma, \& Ukpere, 2015).

Over the years, inventory problems have proliferated, as technological progress has increased the ability of agricultural based institutions to deliver products faster and more efficient. These problems may be attributed to the failure on the part of management, to give a deserved attention to the function of stores and their inability to employ the services of capable employees who would be in charge of supervision and management (Ondari \& Muturi, 2016). The public has compounded the problem by its receptiveness to varieties and changes in customer's needs which must be carefully monitored to ensure that the institution offer a wide range of products to customers and a major key to innovation performance in an agricultural based institution is inventory investment practices.

Inventory is important to any agricultural based institution for production, distribution and maintenance of plant, machineries, goods and operational requirements. While, management of inventory investment is necessary for managing any shortage in inventory items required for production and sale. Any increase in the redundancy of operations connected to shortages in inventory item can drastically lead to loss in production, distribution and its associated cost, hence there is need for proper management of inventories (Nishad \& Kumar, 2018).

However, Nemtajelaand (2017) also stated inventory is primarily concerned with primarily concerned with two areas, which include; serving the customer's needs by having the right goods, in the right place and at the right time; as well as putting into consideration the cost of ordering and carrying inventories.

\section{LITERATURE REVIEW}

\subsection{Inventory Investment Practices}

The word 'inventory' has been defined in several ways from literature. The definitions that would be used are the ones that seem to be more appropriate to the research dissertation. Inventory is the supply of raw materials, work in progress goods and finished foods an organisation maintains so as to meet the operational needs of the organisation. It is also said to represent a sizeable investment and a potential source of waste that needs to be carefully monitored and controlled. Meredith and Shafer, (2019) defined inventory as the "materials and supplies that a business or institution carries either for sale or to provide inputs or supplies to the production proves.

Inventories are a significant portion of an institution's current assets as they represent an important percentage of working capital (Mathuva, 2013). Inventory investment is subject to opportunity cost as a result of tied up cash. Firms cannot do away with inventory just because it ties up cash, but these firms have no alternative than to finance investment in inventory. Therefore, organisational access to finance plays a major role in investment in inventory and its relationship with sustainable performance of the organisation

According to research of Carter (2002), nearly $60 \%$ to $70 \%$ of total finds employed by a firm are tied up in current assets, out of which inventory is the most significant component of the assets. Also inventory represents approximately $20 \%$ of sales revenue for a firm. Investment in inventory is sensitive to cash flow, it implies a cost for organisation making inventory level to increase with an organisations' capacity to generate internal funds (Sodero \& Rabinovich, 2017).

Inventory investment for most institution whether big or small takes up a big chunk of the total budget. The incapacity to relate investment in inventory to the cost of capital is perplexing given the importance of inventory investment over the business cycle. The characteristics of inventory investment varies across countries, periods, cyclical frequencies, industries and components including raw material, work-in-progress and finished goods (Huang J. , 2016)

By utilizing new, flexible, and more refined tools that provide for dynamic optimization of inventories to maximize customer service, throughput, and market share, while decreasing inventory investment and lowering costs, inventory managers can significantly impact overall competitiveness and profitability (Muller, 2019).

In addition, investing in the inventory of raw materials is necessary to avoid suspension in the process of production. Agricultural based invest institution' invest in inventories to prevent production from pausing because this would affect the finished products put up for sales (Ibidunni, Ufua, Okorie, \& Kehinde, 2019). 
Thus, the volume of output that an institution produces depends on the stock of inventories its holds from investing in inventories (Jaamaa, 2018).

Inventories are also held to avoid running out of stocks in a period of unexpectedly high demand. If demand exceeds production and there are no inventories, such institution's produce would be lost to competitors. Avoidance of these stock-outs is an essential motive for investing in holding inventories, as this would affect future sales and profitability (Puga \& Tancrez, 2017).

Agricultural based institutions invest in inventories through by incurring the following inventory costs.

i. Ordering Cost: Ordering cost deals with administrative costs in dealing with production or procurement order, with tracking of orders. Ordering costs are also costs of orering and receiving inventory. Just like shipping cost, odering cost detwermines how much is needed, is used in the preparation of invoices, inspecting goods when they arrive warehouse for quality and quantity check and it is used for moving goods to a temporary storage (Alicke, Rexhausen, \& Seyfert, 2017)..

ii. Holding Costs: This is also known as the carrying cost. It covers costs that are created from storing stocks, stocks that would be traced, depreciation of stocked items and others. The holding cost is also known as the storage cost, and it represents all the costs associated with storing the inventory until such inventory has been sold or used.

iii. Item Costs: It is also known as the purchasing costs. Item costs are the cost of the terms that are held in inventory in an intuition. According to Feng, Chan and Cardenas-Barron (2017) items that are purchased from outside, the costs are the unit price that is paid to the seller. While for items that are produced in the institution, the cost is the value of the item at the point of production which would include material and labour costs.

iv. Shortage cost: This arises from stock out of inventory, as demand cannot be achieved causing orders to be cancelled or placed on procurement order. This arises from stock out of inventory, as demand cannot be achieved causing orders to be cancelled or placed on procurement order. Such costs include opportunity cost of not making a sale, late charges, loss of customer goodwill, cost of lost of production or downtime. Shortage cost are difficult to measure because of subjectivity in making estimates (Stevenson, 2010)

\subsection{Innovation Performance}

Innovation is defined as the generation or adoption of new ideas, objects, or practices. Such generation of innovation results in the adoption and use of an outcome such as a product, service, practice that is new and unique to the state of the art (Damanpour, Sanchez-Henriquez, \& Chiu, 2018).

Innovations are adopted by institutions to improve the products delivered to customers and the society at large, with the broad aim of continuous improvement of quality of life and building better and stronger communities. Innovation is involved and sometimes requires collaboration with outside stakeholders (open innovation), and this act encourages knowledge sharing, risk abatement, and development speed (Rupo, Perano, Centorrino, \& Vargas, 2018). With an increased rate of evolution in consumer tastes and technology, open innovation proves to be indispensable. In past studies, the outcomes of innovations are often measured in terms of innovative output. Such innovative outputs include number of development projects, increase in sales from new products or the frequency of new product launches (Schilling \& Ravi, 2019; Tidd \& Bessant, 2018).

Innovative performance is a new management practice that is intended to sustain performance, and is defined as generation and implementation of management practice, process, structure or technique that is new to the state of the art and is intended to further sustain the performance of the institution (Agboola et al., 2020; Ogunnaike, Bishop, Akinsulire, Kehinde and Oreagbe, 2019). Institutional innovation is an underlying factor that assists institution to survive in a dynamic economy and is perceived to be one of the means by which agricultural based institutions achieve success, this is because it helps the firm outperform its competitors, build new product portfolios and excite customers (Zhang, Khan, Lee, \& Salik, 2019). The basis for agricultural based innovation is found in students who introduce, modify and implement ideas. Therefore institutions rely on the creativity and innovativeness of their students and employees in order to increase institutional innovation performance (Prommarat, 2018). There are different types of innovative performance which are product innovation, process innovation and market innovation, position innovation (Zhang, et al., 2018).

Process innovation can be defined as the adoption of technologically new or significantly improved production methods. Where these methods are concerned with changes in equipment, production 
organisation and may be derived through the use of new technology (OECD, 2005). Process innovation when successful leads to reductions in both the cost and price of the product, eventually leading to pressure on profit levels and in turn, increasing the attractiveness of product innovation. It also helps to induce extra productivity growth during every phase of the process (Iyer \& Soberman, 2016)

According to Damanpour and Schneider (2006), the process innovation can be divided into idea phase which includes activities such as recognizing a need, searching for solutions, studying existing innovations and identifying appropriate innovations for the institution (Damanpour \& Schneider, 2006) After the idea phase comes the development phase which comprises of evaluating the proposed ideas from technical, strategic and financial aspects, making the decision to accept an idea is the desired solution. Implementation phases consists of events that are associated to transforming the innovation, for the use of such innovation, acceptance of the innovation by users of the information and lastly, continued use of the innovation until such innovation becomes a part and parcel of the organization.

Traditionally, marketing innovation is the capacity to re-conceive the existing industry model in ways that create new value for customers, undermine competitors, and produce new wealth for all stakeholders (Hanvanach, Droge and Calatone 2003). Market innovation spanned from the antecedent of marketing insights and marketing imagination. These antecedents represent the capabilities of organisations that make strong contributions to development and fostering of marketing innovation.

According to Cascio (2011), the new marketing innovation conceptualization helps to provide value by doing the following which are to incorporating birth radical and incremental activities into the organisation, distinguishing it from product and process innovation, maintaining the current or prospective customer as primary stakeholder, embracing the boundary spanning perspective and creating distinction from improvements and invention.

\section{METHODOLOGY}

Descriptive research design was used for this study with the aid of survey to make it possible for the collection of data from a substantial number of persons at the same time. The sample design for this procedure is simple random sampling technique. A regression analysis was used to test the casual effect between the two variables of inventory investment practices and innovation performance of the selected agricultural based institution

\section{FINDINGS}

Ho: Inventory investment practices does not affect to the innovation performance

Table 1 Model Summary

\begin{tabular}{|l|l|l|l|l|}
\hline Model & $\mathrm{R}$ & $\mathrm{R}$ Square & Adjusted R Square & Std. Error of the Estimate \\
\hline 1 & $.616^{\mathrm{a}}$ & .380 & .373 & .29182 \\
\hline
\end{tabular}

(Source: Survey 2020)

The table presents the results that revealed the extent to which the variance in innovation performance explained by inventory investment practices. This is denoted by $R$ square which equals .380 and expressed in percentage is $38 \%$. This shows that Inventory investment practices only accounts for $38 \%$ of innovation performance, while the standard error estimate is .29182 which signifies error term.

Table 2:ANOVA ${ }^{\mathrm{a}}$

\begin{tabular}{|l|c|c|c|c|c|c|}
\hline \multicolumn{2}{|c|}{ Model } & Sum of Squares & Df & Mean Square & F & Sig. \\
\hline \multirow{3}{*}{1} & Regression & 5.005 & 1 & 5.005 & \multirow{2}{*}{58.770} & \multirow{2}{*}{$.000^{\mathrm{b}}$} \\
\cline { 2 - 5 } & Residual & 8.175 & 96 & .085 & \\
\cline { 2 - 4 } & Total & 13.180 & 97 & & \\
\hline \multicolumn{2}{ll}{ a. Dependent Variable: Innovation Performance } \\
b. Predictors: (Constant), Inventory Investment Practices \\
\hline
\end{tabular}

(Source: Survey 2020) 
Decision Rule: Null hypothesis should be rejected when the significance value is below 0.05 . Null hypothesis should be accepted when the significance value is greater than 0.05 .

Interpretation of Result: The ANOVA table shows that the F value is 58.770 at $.000^{\mathrm{b}}$ Significance level. The implication is that inventory investment practices have a significant effect on innovation performance of agricultural based institutions.

Decision: The Null hypothesis is therefore rejected because the significance value is below 0.05 . Therefore, there is a significant influence of inventory investment practice on innovation performance.

Table 3: Coefficients ${ }^{\mathrm{a}}$

\begin{tabular}{|c|c|c|c|c|c|c|}
\hline & \multirow[t]{2}{*}{ Model } & \multicolumn{2}{|c|}{ Unstandardized Coefficients } & \multirow{2}{*}{$\begin{array}{c}\begin{array}{c}\text { Standardized } \\
\text { Coefficients }\end{array} \\
\text { Beta }\end{array}$} & \multirow[t]{2}{*}{$\mathrm{t}$} & \multirow[t]{2}{*}{ Sig. } \\
\hline & & B & Std. Error & & & \\
\hline \multirow[b]{2}{*}{1} & (Constant) & .1 .493 & .274 & \multirow[t]{2}{*}{.616} & 5.451 & .000 \\
\hline & $\begin{array}{c}\text { Inventory } \\
\text { Management } \\
\text { Practices }\end{array}$ & .590 & .077 & & 7.666 & .000 \\
\hline
\end{tabular}

(Source: Survey 2020)

Interpretation of Result: The table above shows inventory investment practice has an effect on innovation performance and their level of significance. $(\beta=.616 ; t=7.666 ; p<0.05)$

Decision; since the significance level of the model is less than 0.05 , the null hypothesis should be rejected while the alternative hypothesis is accepted. It can therefore be concluded that inventory investment practices has a significant effect on innovation performance of agricultural based institutions.

The study found that inventory investment as it relates to inventory cost is an important approach to achieving innovation performance thereby increasing institutional performance. This is in line with the study of Caplice and Shafi (2004) who were of the view that inventory utilization is a crucial factor for management of innovation efficiency and effectiveness.

\section{CONCLUSION}

Effective investment in inventory is recognized as one of the inventory management practices of agricultural based firms that would improve innovation performance of such institution. The ability to invest in inventory will then depend on the extent to which it can incur cost that would end up benefit the organization as a whole. However, to achieve all these, institutions must maintain a proper inventory investment forum for higher innovation performance. Thus, the study found that there is a significant effect of inventory investment practices and innovation performance of agricultural based institutions.

\section{REFERENCE LIST}

Agboola, M. G., Motilewa, D. B., Salau, O., Kehinde , B. E., Ogueyungbo, O., Akinbode, M., . . Atolagbe, T. 2020. Models and approahes for management of organizational crisis: Best practices for organizational success. 14th International Technology, Education and Development Conference. Valencia, Spain: INTED2020 Proceeding.

Alicke, K., Rexhausen, D., \& Seyfert, A. (2017). Supply Chain 4.0 in consumer goods. Mckinsey \& Company.

Caplice, C. and Sheffi, V. (1994). A Review and Evaluation of Logistic Metrics. The International Journal of Logistics Management, 5(2): 23-37.

Damanpour, F., Sanchez-Henriquez, F., \& Chiu, H. H. (2018). Internal and external sources and the adoption of innovations in organizations. British Journal of Management, 29(4), 712-730. 
Huang, J. (2016). A Review of Inventory Investment: The Macro and Micro Perspective. Journal of Financial Risk Management, 50(1), 57.

Ibidunni, A. S., Ufua, D. E., Okorie, U. E., \& Kehinde, B. E. (2019). Labour productivity in agricultural sector of Sub-Sahara Africa (2010-2017): A data envelopment and panel regression approach. African Journal of Economic and Management Studies, 11(2), 207-232.

lyer, G., \& Soberman, D. A. (2016). Social responsibility and product innovation. Marketing Science, 35(5), 727-742.

Jaamaa, J. (2018). From Product Assortment to Inventory Planning. Master Thesis submitted to Lahti University of Applied Sciences.

Mathuva, D. M. (2013). Determinants of corporate inventory holdings: evidence from a developing country. International Journal of Applied Economics and Fiance, 7(13), 1-22.

Muller, M. (2019). Essentials of inventory management. HarperCollins Leadership.

Ogbo, A. I., Onekanma, I. V., \& Ukpere, W. I. (2015). The impact of effective inventory control management on organisational performance: A study of 7 up bottling company. Mediterranean Journal of Social Sciences, 5(10), 109-118.

Ogunnaike, O. O., Bishop, S. A., Akinsulire, H., Kehinde, B. E., \& Oreagba, O. T. 2018. Education for sale: Markov chain analysis of physical qualities and engineering students switching behaviour. International Journal of Mechanical Engineering and Technology, 9(12), 230-239.

Ondari, L. M., \& Muturi, W. (2016). Factors affecting the efficiency of inventory management in organizations in Kenya. International Journal of Economics, Commerce and Management, 4(4), 1019-1034.

Prommarat, P. (2018). Effects of the Antecedent Variable on Strategic Organizational Flexibility Capability: An Empirical Investigation of Tour Businesses in Thailand. Journal of Roi Et Rajabhat University, 12, $1-13$.

Puga, M. S., \& Tancrez, J. S. (2017). A heuristic algorithm for solving large location-inventory problems with demand uncertainty. European Journal of Operational Research, 259(2), 413-423.

Rupo, D., Perano, M., Centorrino, G., \& Vargas, S. A. (2018). Rupo, D., Perano, M., Centorrino, G., \& Vargas-Sanchez, A. (2018). A framework based on sustainability, open innovation, and value cocreation paradigms-a case in an Italian maritime cluster. Sustainability, 10(3), 729.

Schilling, M. A., \& Ravi, S. (2019). Strategic management of technological innovation. UK: McGraw-Hill Education.

Sodero, A. C., \& Rabinovich, E. (2017). Demand and revenue management of deteriorating inventory on the Internet: an empirical study of flash sales markets. Journal of Business Logistics, 38(3), 170-183.

Stevenson, B. U. (2010). Operations management (10th edn.). New York: McGraw-Hill Publishing Inc.

Tidd, J., \& Bessant, J. R. (2018). Managing innovation: integrating technological, market and organizational change. . UK: John Wiley \& Sons.

Zhang, Y., Khan, U., Lee, S., \& Salik, M. (2019). The influence of management innovation and technological innovation on organization performance. A mediating role of sustainability. Sustainability, 11(2), 495. 